\title{
THE EFFECT OF NARCOTICS ON THE ENDOGENOUS RESPIRATION AND SUCCINATE OXIDATION IN OYSTER MUSCLE
}

\author{
By George Frederick Humphrey \\ Department of Biochemistry, University of Sydney, Australia
}

(Text-figs. I-6)

\section{INTRODUCTION}

The adductor muscles of Lamellibranchs present unusual features in their physiology. Thus it has been known for some time (Marceau, I909) that they are able to support relatively large tensions, and the morphological differentiation into nacreous and vitreous parts in some species has led various workers (Parnas, I910; Boyland, I928; and Kobayashi, 1929) to attempt to correlate differences in metabolism with these properties. Also, Riesser (1933) has investigated, by the usual pharmacological techniques, the action of a number of compounds on invertebrate muscle, and concluded that these smooth muscles behaved similarly to cross-striated frog muscle. More recently, some features of the glycolytic mechanism (Humphrey, 1943) and of the succinoxidase system (Humphrey, 1947) in the adductor muscles of Saxostrea commercialis have been established. It was shown that succinic acid was able to increase the oxygen consumption considerably, and the effects of various inhibitors on the oxygen uptake in the presence and absence of succinic acid were determined.

In continuation of this, it was thought desirable to determine the effects of other classes of inhibitors on the oxygen consumption, and, with this object in view, the action of narcotics was studied. The effect of narcotics on the oxidation of succinic acid was also determined, since succinic acid plays such a central role in tissue metabolism (Szent-Györgyi, I937). Also, Quastel \& Wheatley (I933) have found that, in general, the oxidation of succinic acid by brain tissue is, unlike the oxidation of numerous other substrates, insensitive to the presence of narcotics; it therefore becomes important to determine if such insensitivity occurs with the muscle taken from Saxostrea.

\section{Materials AND Methods}

Specimens of Saxostrea commercialis were obtained from the C.S.I.R. Experimental Farm at George's River, Sydney, Australia; only adult animals, 2-3 years old, were used. 
The narcotics were used as neutralized aqueous solutions. Salicylamide was prepared by the method of Anschütz (I9I9); the other compounds were chemically pure commercial specimens.

Cytochrome was prepared from pig heart by the method of Keilin \& Hartree (1937), but was dialysed against distilled water (Potter, I94I).

The adductor muscles, immediately after dissection, were homogenized at a $30 \%$ concentration with water in the instrument previously described (Humphrey, 1946). The desired amount of narcotic in $2 \mathrm{ml}$. of water was placed in a manometer flask, together with neutralized sodium succinate (to give a final concentration of $0.05 \mathrm{M}$ ) if the oxidation of this substance was being studied. $2 \mathrm{ml}$. of the muscle suspension was then pipetted into the flask, and the oxygen consumption measured under the conditions already given (Humphrey, I946). When used, cytochrome was added directly to the main compartment of the manometer flask, to give a final concentration of $1 \mathrm{O}^{-5} \mathrm{M}$.

\section{ResUlTS}

The main results are set out in Figs. I-6, and Table I. Two or three concentrations of each narcotic were studied, depending on the solubility of the compound in question. Included with each set was a control with water in place of narcotic, and oxygen consumption was always recorded at I and $2 \mathrm{hr}$. Using the $2 \mathrm{hr}$. reading, the inhibition was then calculated as a percentage of the control, and the mean of several values graphed against the concentration of narcotic or the logarithm of the concentration.

\section{Table I. Effect of Urethanes, Salicylamide, and Chloral Hydrate}

\begin{tabular}{|c|c|c|c|c|c|}
\hline Inhibition (\%) by & $\ldots$ & Endogenous & $\begin{array}{l}\text { Endogenous } \\
\text { + cytochrome }\end{array}$ & $\begin{array}{l}\text { Succinic } \\
\text { acid }\end{array}$ & $\begin{array}{l}\text { Succinic acid } \\
\text { + cytochrome }\end{array}$ \\
\hline Urethane & $\begin{array}{l}0.001 \mathrm{M} \\
0.01 \mathrm{M} \\
0.05 \mathrm{M}\end{array}$ & $\begin{array}{r}6 \\
18 \\
-6\end{array}$ & $\begin{array}{r}5 \\
15 \\
-6\end{array}$ & $\begin{array}{l}\text { I5 } \\
21 \\
30\end{array}$ & $\begin{array}{r}9 \\
14 \\
17\end{array}$ \\
\hline Phenyl urethane & $\begin{array}{l}0.001 \mathrm{M} \\
0.005 \mathrm{M}\end{array}$ & $\begin{array}{l}30 \\
47\end{array}$ & $\begin{array}{l}39 \\
56\end{array}$ & $\begin{array}{l}33 \\
54\end{array}$ & $\begin{array}{l}20 \\
60\end{array}$ \\
\hline Salicylamide & $\begin{array}{l}0.001 M \\
0.01 M\end{array}$ & $\begin{array}{l}\text { I0 } \\
50\end{array}$ & $\begin{array}{l}\text { I5 } \\
54\end{array}$ & $\begin{array}{l}29 \\
63\end{array}$ & $\begin{array}{l}33 \\
70\end{array}$ \\
\hline Chloral hydrate & $\begin{array}{l}0.001 \mathrm{M} \\
0.01 \mathrm{M}\end{array}$ & $\begin{array}{l}25 \\
50\end{array}$ & $\begin{array}{l}15 \\
38\end{array}$ & $\begin{array}{l}13 \\
64\end{array}$ & $\begin{array}{l}\text { IO } \\
4 \mathrm{I}\end{array}$ \\
\hline
\end{tabular}

On the whole, straight lines are obtained when the logarithmic plotting is used, but sometimes (Figs. 5 and 6 ) the inhibition is directly proportional to the concentration. These differences may be compared with the sigmoid curves obtained by Jowett \& Quastel (1937). Replacement of the carboxyl group of benzoic acid with an acid amide group always increases the inhibition, but the reverse is true for salicylic acid and salicylamide. At equal concentrations, phenyl urethane is a better inhibitor than ethyl urethane, and the latter, at a concentration of $0.05 \mathrm{M}$, causes a slight increase in the oxygen consumption. 
All the narcotics inhibit succinate oxidation, and usually more strongly than the endogenous respiration. On the whole, the addition of cytochrome does

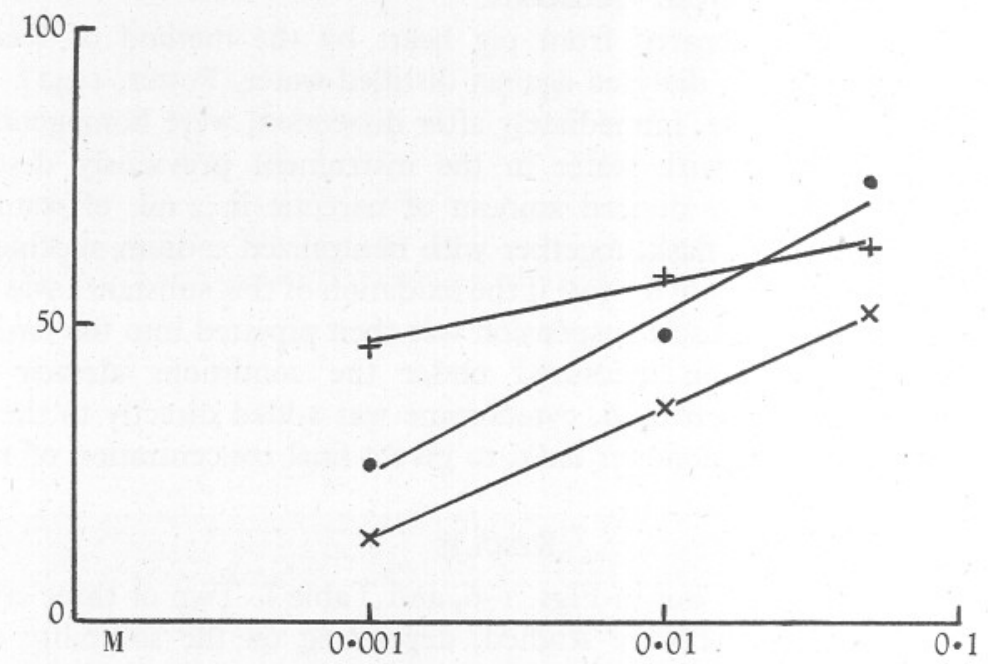

Fig. I. Effect on endogenous oxygen consumption. Ordinates are percentage inhibition; abscissae, molarity of narcotic. - benzamide; + salicylate; $\times$ benzoic acid.

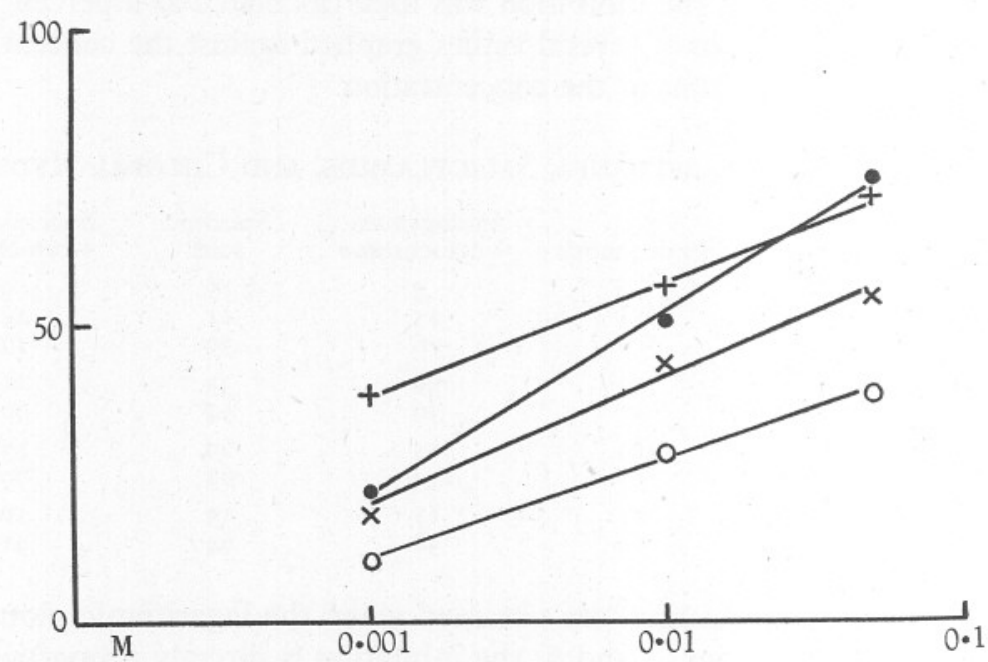

Fig. 2. Effect on endogenous oxygen consumption in the presence of cytochrome. Ordinates are percentage inhibition; abscissae, molarity of narcotic. - benzamide; + salicylate; $\times$ benzoate; 0 morphine.

not affect the inhibition of the endogenous or succinate respiration; marked exceptions are the effects on the endogenous respiration of $0.025 \mathrm{M}$ barbitone, where the inhibition drops from 48 to $20 \%$ (Fig. 5), and $0.05 \mathrm{M}$ morphine, 
where $67 \%$ changes to $40 \%$ after the addition of cytochrome (Fig. 6). The variations in inhibition caused by the addition of cytochrome and/or succinate

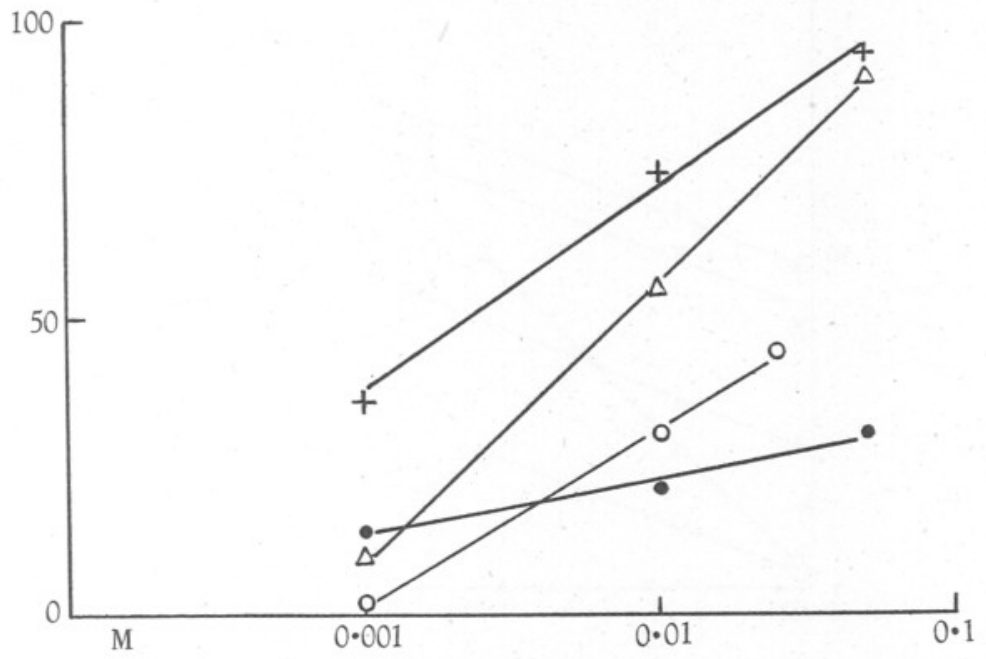

Fig. 3. Effect on succinate oxidation. Ordinates are percentage inhibition; abscissae' molarity of narcotic. + salicylate; $\Delta$ caffeine; $O$ barbitone; $\bullet$ urethane.

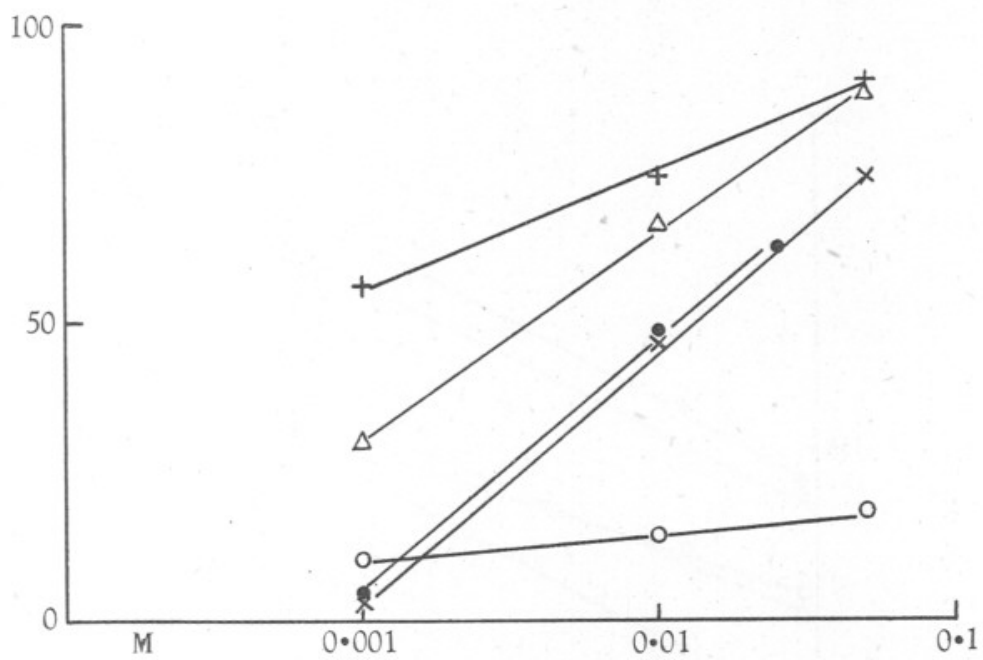

Fig. 4. Effect on succinate oxidation in the presence of cytochrome. Ordinates are percentage inhibition; abscissae, molarity of narcotic. + salicylate; $\Delta$ caffeine; $\times$ benzoate; - barbitone; O urethane.

may be due to the fact that in the endogenous respiration several systems are functioning at more or less similar rates, whereas, after these additions, certain pathways become more prominent. 


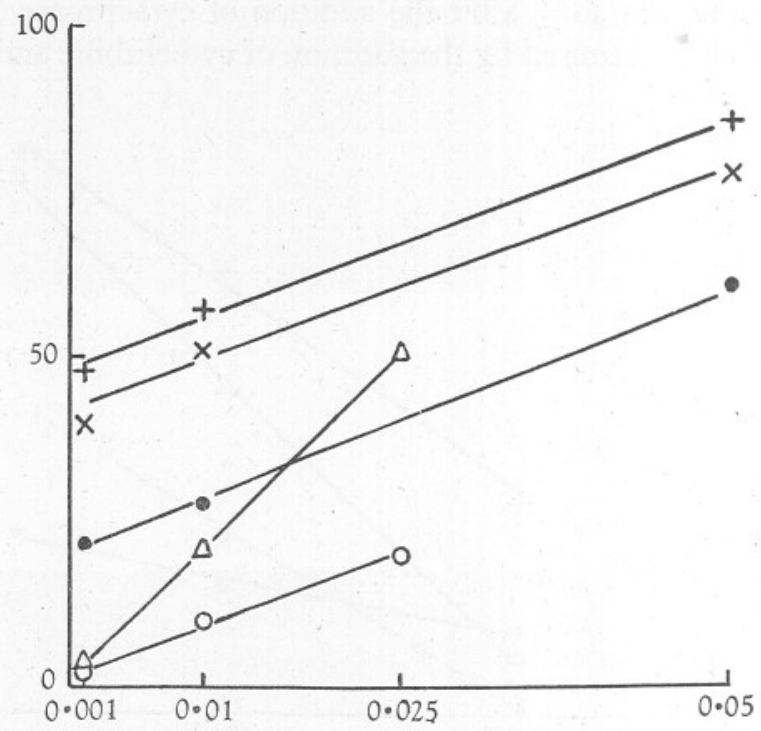

Fig. 5. Effect on endogenous oxygen consumption. Ordinates are percentage inhibition; abscissae, molarity of narcotic. + caffeine in the presence of cytochrome; $\times$ caffeine; $\Delta$ barbitone; $\bullet$ morphine; $O$ barbitone in the presence of cytochrome.

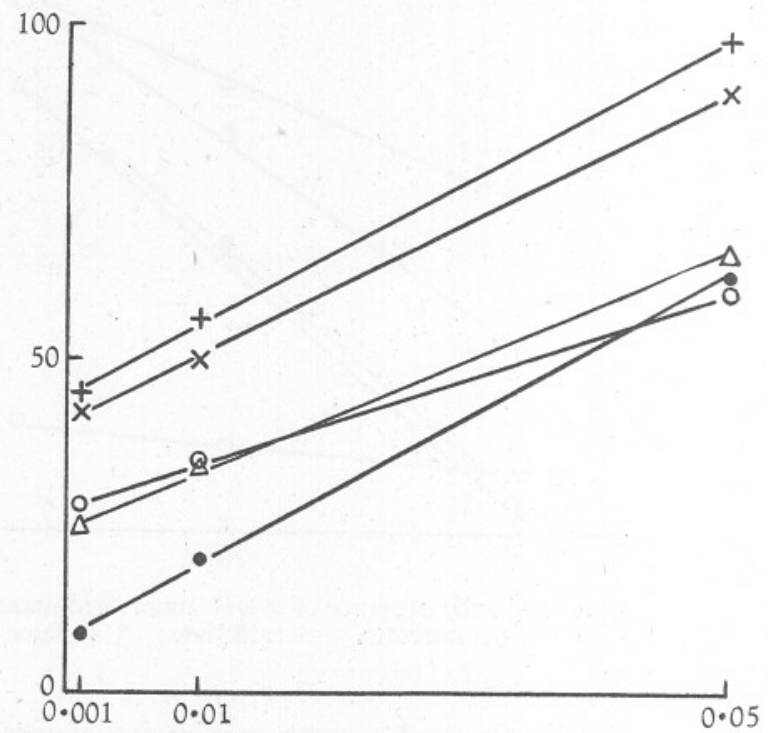

Fig. 6. Effect on succinate oxidation. Ordinates are percentage inhibition; abscissae, molarity of narcotic. + benzamide in the presence of cytochrome; $\times$ benzamide; $\triangle$ benzoate; - morphine; $O$ morphine in the presence of cytochrome. 
It was not possible to increase the inhibition by incubation of the tissue suspension and narcotic for $30 \mathrm{~min}$. before tipping in the succinate from a side arm. Similar incubation of the tissue and succinate, followed by the addition of narcotic, gave slightly less inhibition. This could be interpreted by assuming that there was substrate-narcotic competition for a definite site of attachment in the suspension.

\section{Discussion}

Keys (I937) has stated that it is a 'fundamental fact that narcotized cells no longer show or transmit irritable impulses... in narcotic doses, true narcotics do not seriously interfere with the total resting metabolism of the cell'. Since it is not known what a 'narcotic dose' for Saxostrea is, it is not possible to deny or affirm the latter part of this statement. Also, in general, it is desirable to reserve the concept of narcosis for the action of certain classes of substances on whole organisms, or cell preparations which approximate closely to physiological conditions. The system studied here can be regarded as 'intermediate' (Clark, I937) and the use of the term narcotic must be regarded as a convenient way of designating a type of compounds.

The most widely accepted explanation of the action of narcotics on cells is the Meyer-Overton theory which seeks to correlate the activity with the solubility of the narcotic in lipoid phases. However, this does not give an explanation of the phenomena observed with partially isolated enzyme systems. Michaelis \& Quastel (I94I) investigated the effect of chloretone on various dehydrogenase systems, and came to the conclusion that this narcotic has its effect mainly on flavoprotein, or an unknown component intermediate between flavoprotein and cytochrome oxidase. Östergren (I944) suggests that narcotics can associate with the lipophilic side chain of polypeptides and change the folding pattern; perhaps this is how chloretone affects the flavoprotein. However, there is no conclusive evidence for these theories, and the action of a given narcotic seems to vary from one organism to another, suggesting that there is more involved than a relatively simple relationship between narcotic and chemical grouping.

\section{Endogenous Oxygen Consumption}

Urethanes have been used extensively on different organs and isolated respiratory systems. Warburg (I9I4) showed that phenyl urethane was a more powerful inhibitor of erythrocyte respiration than ethyl urethane. Krogh (I9I5) demonstrated that ethyl urethane is suitable for narcotizing various marine animals; in general 0.05-0.IM was sufficient. Navez, Crawford, Benedict \& Dubois (I94I), working on the oxygen consumption of the heart of Venus mercenaria, showed that 0.0I M urethane caused an increase of $20 \%$. Moog \& Spiegelman (I942) found that neither ethyl nor phenyl urethane affected the oxygen uptake of stems cut from Tubularia. However, Barnes 
(I944) obtained an inhibition of the respiration of developing eggs of Rana pipiens with $0.2 \mathrm{M}$ urethane. Nothing similar to the break in activity-concentration relationship found with Saxostrea muscle has been previously observed in animal tissue.

Cheney (1946) obtained $60 \%$ inhibition of the oxygen uptake of fertilized Arbacia eggs in the presence of O. I M caffeine. He concluded, with little direct evidence, that caffeine acts on the cytochrome oxidase. On the whole, caffeine is one of the most effective narcotics for inhibiting the endogenous respiration of Saxostrea muscle.

Regarding the effects of the narcotics studied here, there has not yet been reported any other information with which it would be possible directly to compare the findings obtained with Saxostrea. However, Shideman \& Seevers (I94I), using rabbit muscle, found that 0.00017-0.0017 M morphine increased the oxygen consumption. No such acceleration was observed with Saxostrea muscle when $0.00 \mathrm{I}-0.05 \mathrm{M}$ morphine was used.

\section{Oxidation of Succinic Acid}

Assuming that added succinic acid causes an increase of about $300 \%$ in the oxygen consumption (Humphrey, 1947), an examination of Figs. I-6 reveals that the oxidation of succinic acid is inhibited by all the narcotics used. Only with $0.001 \mathrm{M}$ benzoic acid and $0.001 \mathrm{M}$ chloral hydrate is the oxidation uninhibited, and this only in the presence of added cytochrome. These findings are in direct contrast to those of Quastel \& Wheatley (1933), Jowett \& Quastel (I937) and Seevers \& Shideman (I94I), who found that, for vertebrate tissue, the oxidation of succinic acid is unaffected by a large number of narcotics when these are present in concentrations of about $0.01 \mathrm{M}$.

Also, Greig (1946), basing her arguments on the work of Jowett \& Quastel (1937) and Michaelis \& Quastel (I94I), i.e. on the insensitivity of the oxidation of succinate to narcotics, showed that the site of action of nembutal is the flavoprotein-cytochrome $b$-link of the respiratory chain; these experiments were with yeast and brain and cannot be directly compared with observations on invertebrate tissue.

\section{ConCLUSIONS}

As might be expected, the effects of narcotics on Saxostrea muscle differ quantitatively from those obtained with vertebrate muscle. In addition, there are two qualitative differences; namely, the break in activity-concentration relationship shown with urethane, and also the inhibition of the oxidation of succinic acid. In these two respects, Saxostrea muscle is distinguished from other tissues.

However, it is not possible to conclude that the role of succinic acid in the metabolism of the adductor muscle differs fundamentally from that in other muscle. Also, the changes in narcotic effect due to the presence of added 
cytochrome are not sufficiently definite to indicate that the metabolic pattern is changed by added cytochrome. With regard to the site of action of the narcotics used, definite conclusions must await an elucidation of the main respiratory pathways operating in this invertebrate tissue.

\section{SUMMARY}

The action of the following compounds on homogenates of the adductor muscles of Saxostrea commercialis was studied: urethane, phenyl urethane, chloral hydrate, salicylic acid, morphine, caffeine, barbitone, benzoic acid, salicylamide and benzamide.

It was found that, except for $0.05 \mathrm{M}$ urethane, the endogenous oxygen consumption was reduced by all these compounds when present in concentrations ranging from $0.00 \mathrm{I}$ to $0.05 \mathrm{M}$. The oxidation of succinic acid was partially inhibited by these substances.

These findings are discussed in relation to similar studies on other tissues.

\section{REFERENCES}

ANSCHÜtz, R., I9I9. Über ein neues Disalicylid. Ber., Vol. LII, pp. 1875-95.

BARNES, M. R., I944. The metabolism of the developing Rana pipiens as revealed by specific inhibitors. Fourn. Exp. Zool., Vol. xCV, pp. 399-4I7.

Boyland, E., I928. Chemical changes in muscle. Part I. Invertebrate muscle. Part 2. Vertebrate cardiac muscle. Biochem. Fourn., Vol. xxiI, pp. 362-80.

Cheney, R. H., I946. The effects of caffeine on the oxygen consumption and cell division in the fertilized egg of the sea urchin, Arbacia punctulata. Fourn. Gen. Physiol., Vol. xxIx, pp. 63-72.

Clark, A. J., I937. The action of narcotics on enzymes and cells. Trans. Farad. Soc., Vol. XxxiII, pp. I057-61.

GREIG, M. E., I946. The site of action of narcotics on brain metabolism. Fourn. Pharm. Exp. Ther., Vol. LxxxviI, pp. 185-92.

Humphrey, G. F., 1943. Glycolysis in extracts of oyster muscle. Aust. Fourn. Exp. Biol. Med. Sci., Vol. xxII, pp. 135-38.

- I946. The endogenous respiration of homogenates of oyster muscle. Aust. fourn. Exp. Biol. Med. Sci., Vol. xxiv, pp. 26I-67.

- 1947. The succinoxidase system in oyster muscle. Fourn. Exp. Biol., Vol. xxiv, pp. 352-60.

JowetT, M. \& QuASTEL, J. H., I937. The effects of narcotics on tissue oxidations. Biochem. Fourn., Vol. xxxi, pp. 565-78.

KeIlin, D. \& Hartree, E. F., I937. Preparation of pure cytochrome $c$ from heart muscle and some of its properties. Proc. Roy. Soc. Lond., B, Vol. cxxir, pp. 298308.

Keys, A., I937. Contributions to the theory of narcosis. Trans. Farad. Soc., Vol. XXXIII, pp. I064-65.

KoBAYASHI, S., I929. Lactic acid and glycogen in the adductor muscles of the oyster, Ostrea circumpicta Pils. Sci. Rep. Tohoku Imp. Univ., Vol. Iv, Ser. 4, pp. I93-205.

KROGH, A., I915. Ethyl urethane as a narcotic for aquatic animals. Internat. Rev. Hydrobiol. Hydrograph., Vol. viI, pp. 42-47. 
MARCEAU, F., I909. Recherches sur la morphologie, l'histologie et la physiologie comparées des muscles adducteurs des mollusques acephales. Arch. Zool. exp. gen., T. II, Ser. 5, pp. 295-469.

MICHAELIS, M. \& QUASTEL, J. H., I94I. The site of action of narcotics in respiratory processes. Biochem. Fourn., Vol. xxxv, pp. 518-33.

Moog, F. \& SpIegelman, S., I942. Some effects of respiratory inhibitors on respiration and reconstitution in Tubularia. Proc. Soc. Exp. Biol. Med., Vol. xLIx, pp. 392-95.

Navez, A. E., Crawford, J. D., Benedict, D. \& Dubois, A. B., I94I. On the metabolism of the heart of Venus mercenaria. Biol. Bull. Woods Hole, Vol. Lxxxi, p. 289.

ÖSTERGREN, G., I944. Colchicine mitosis, chromosome contraction, narcosis, and protein chain folding. Hereditas, Vol. xxx, pp. 429-67.

Parnas, J. K., I9I0. Energetik glatter Muskeln. Pfluegers Arch. ges. Physiol., Bd. CXxxIV, pp. 44I-95.

PotTeR, V. R., I94I. Studies on the mechanism of hydrogen transport in animal tissues. IV. The succinoxidase system. Fourn. Biol. Chem., Vol I4I, pp. 775-87.

Quastel, J. H. \& Wheatley, A. H., I933. Narcosis and oxidations of the brain. Proc. Roy. Soc. Lond., Vol. cxir, pp. 60-79.

RIESSER, O., 1933. Fortgesetzte pharmacologische Untersuchungen an den Muskeln wirbelloser Meerestiere. Arch. exp. Path. Pharm., Bd. CLXxII, pp. I94-2I2.

SeEvers, M. H. \& Shideman, F. E., I94I. Effects of morphine and its derivatives on intermediate metabolism. I. The influence of morphine, codeine and thebaine on the activity of several dehydrogenases and on the respiration of rat cerebrum. f. Pharm. Exp. Ther., Vol. LxxI, pp. 373-82.

SHIDEMAN, F. E. \& SEevers, M. H., I94I. Effects of morphine and its derivatives on intermediate metabolism. II. The influence of thiamin deficiency on the respiration of skeletal muscle and cocarboxylase content of tissues of normal and chronically morphinized rats. Fourn. Pharm. Exp. Ther., Vol. LxxI, pp. 383-93.

SZENT-GYöRGYI, A., I937. Studies on biological oxidation and some of its catalysts. Acta med. Szeged., Vol. IX, pp. I-79.

WARBURG, O., Ir9I4. Über Verbrennung der Oxalsäure an Blutkohle und die Hemmung dieser Reaktion durch indifferente Narkotica. Pfluegers Arch. ges. Physiol., Bd. CLV, pp. 547-66. 